\title{
WAYS TO INTERPRET TAX LEGISLATION
}

\section{Igor Samsin}

\section{INTRODUCTION}

An urgent need in Ukraine was to ensure the consistency of case law. Such unity is in the countries of the European Community and in the Anglo-Saxon legal system. This is due to the processes of globalization and prospects for European integration of Ukraine. The established and unique jurisprudence in these countries has been shaped for centuries. Ukraine should establish such practices in a short time.

It is possible, if it comes the realization that time intuitive, artistic, organoleptic, associative and irrational law passed. It is a rational law. The onset of this delayed time with the reason that, until recently, either in our country or in other countries are not carried out a thorough study on the interpretation of regulations. These studies gave us the opportunity to see the full range of logical and legal means, the use of which reveals the content of the provisions of legal acts in their system.

In general, all processes occurring in the field of law: law-making, lawenforcement and law-interpreting, because these processes are intellectual and designed to make their outcome accessible and understandable to everyone. Achieving this criterion is possible only if the fundamental principles of these processes will have a universal character of logical thinking.

Considering interpretation as an intellectual activity, A. Cherdantsev proceeded from the fact that this is the process of logical deduction and proving the truth of our knowledge about the content of the rules of law, in the course of which apply all the laws and techniques that are in the arsenal of $\operatorname{logic}{ }^{1}$. From this point of view, he indicated that all ways of interpretation are logical. However, the researcher singled out logical interpretation in the narrow sense, as a separate way of interpretation, understanding the interpretation in which the interpreter with the help of purely logical techniques operates the material of the most interpreted norm, without going beyond its boundaries, without resorting to other norms of law (logical transformation, the conclusion from the previous to the next, the conclusion from the opposite, the following from the concepts, the conclusions of the

\footnotetext{
${ }^{1}$ Cherdantsev A.F. (1972). Voprosy tolkovaniya sovetskogo prava [Interpretation issues of Soviet law]. (p. 79) Sverdlovsk [in Russian].
} 
degree, the derivation of norms from norms, analogy, bringing to the absurd and etc. $)^{2}$.

An important part in the interpretation issue is the approach to clarifying the meaning of the acts disclosed in certain rules and techniques, which in turn defines different ways of interpreting acts of tax law. In turn, these tools make it possible to see in legal acts all their legal content, which today the average lawyer sees less than fifty percent.

The established methods of elaboration of normative texts make it possible to constructively solve a number of problems that are solved unilaterally and unconstructively without this knowledge. These are the problems of correlation of natural and positivist legal thinking, judicial lawmaking, contra legem court decisions, algorithm of interpretation, application of the principles of law, especially the principle of the rule of law, the analogy of the law and law.

\section{Approaches to the classification of ways of interpreting acts of tax legislation}

One of the most important tools for regulating public relations is law. It acts as a regulator and a means of direct managerial influence. Norms of law encourage people to engage in active behavior, punish, prohibit, or allow specific actions. Norms of law are usually understood to be a formally binding rule of physical conduct, of a general nature, established or sanctioned by the state for the purpose of regulating public relations and provided with appropriate safeguards for its implementation ${ }^{3}$. From how state will is formulated in law, largely depends on the effectiveness of its implementation, its understanding of the performers, compliance with their actions to the requirements of law ${ }^{4}$.

The constitution and laws must be interpreted in accordance with certain rules. Only then can an adequate understanding and clarification of legal rules be relied upon ${ }^{5}$.

The purpose of clarifying the meaning of a rule is to interpret it as a process based on the application of methods and techniques that allow the formulation of a lawful (logical) rule.

\footnotetext{
${ }^{2}$ Cherdantsev A.F. (1972). Voprosy tolkovaniya sovetskogo prava [Interpretation issues of Soviet law] (p. 81) Sverdlovsk [in Russian].

${ }^{3}$ Shemshuchenko Yu.S. (Eds.) (2003). Jurydychna encyklopedija [Legal Encyclopedia] (Vols. 1-6) (Vol. 4). Kyiv: Ukrainska Encyklopediya [in Ukrainian].

${ }^{4}$ Alekseev S.S. (1999). Sotsial'naya tsennost' prava v sovetskom obshchestve [The social value of law in Soviet society]. Moscow: Yuridichtskaya Literatura [in Russian].

${ }^{5}$ Todyka Yu.M. (2001). Tlumachennja konstytuciji i zakoniv Ukrajiny: teorija i praktyka: monoghraf [Interpretation of the constitution and laws of Ukraine: theory and practice: monograph]. (p. 122) Kharkiv: Fakt [in Ukrainian].
} 
The method of interpretation in the literature refers to a set of homogeneous techniques and rules of interpretation ${ }^{6}$. Namely, according to S. Alekseev, the method of interpretation is a general concept, which also includes methods of interpretation. Indeed, the admission is a "specific cognitive action" that is realized within the limits of a particular mode of interpretation and obeys the laws and rules of this method.

The eminent jurist E. Vaskovskii the interpretation as such is generally defined through the techniques, indicating that the interpretation, or interpretation, is a set of techniques used in the creativity of people in order to understand its essence ${ }^{8}$.

Among the techniques of the interpretation are called comparison, analogy, the derivation of one knowledge from another. ${ }^{9}$ Special interpretation is also in isolation from the letter of the law or associative interpretation ${ }^{10}$.

Ukrainian scientists M. Kelman and O. Murashyn define a way of interpretation as a set of techniques and means that allow to find out the content of a rule of law and expressed the purpose in of their implementation ${ }^{11}$.

It is difficult to agree with the proposed definition, since the reference to "means" of interpretation means references to the logistical, intellectual factors that usually affect the interpretation process in each case, but do not form the basis of its methodology.

It is advisable to offer another definition of how to interpret tax legislation: it is a system of approaches to clarifying the content (meaning) of acts disclosed in specific rules and techniques, the application of which allows to establish a logical rule of tax law to overcome defective legal material with the purpose establishing the true value of the rule of law to be applied to the disputed case.

\footnotetext{
${ }^{6}$ Alekseeva S.S. (Ed.) (1987) Problemy teorii gosudarstva i prava [Problems of the theory of state and law]. (p. 397) Moscow: Yuridichtskaya Literatura [in Russian].

${ }^{7}$ Voplenko N.N. (1993). Tolkovanie prava. Obshchaya teoriya prava [The interpretation of law. General Theory of Law] kurs lektsiy, (p. 373). Nizhniy Novgorod [in Russian].

${ }^{8}$ Vas'kovskiy E.V. (1913). Rukovodstvo k tolkovaniyu i primeneniyu zakonov: dlya nachinayushchikh yuristov [Guide to the Interpretation and Application of Laws: For Beginners]. (p. 32) Moscow : Br. Bashmakovykh [in Russian].

${ }^{9}$ Voplenko N.N. (1993). Tolkovanie prava. Obshchaya teoriya prava [The interpretation of law. General Theory of Law] kurs lektsiy, (p. 373). Nizhniy Novgorod [in Russian].

${ }^{10}$ Rotanj V. (Ed.) (2008) Naukovo-praktychnyj komentar do cyviljnogho zakonodavstva Ukrajiny [Scientific and practical commentary on the civil legislation of Ukraine] (Vols. 1-4) Metodologhija tlumachennja normatyvno-pravovykh aktiv Ukrajiny [Methodology of interpretation of normative legal acts of Ukraine] (Vol. 3) (p. 328) Kyiv: Juryd. kn.; Sevastopolj: In-t juryd.doslidzhenj [in Ukrainian].

${ }^{11}$ Keljman M.S., Murashyn O.Gh. (2006). Zaghaljna teorija derzhavy i prava [General theory of state and law] Kyiv: Kondor [in Ukrainian].
} 
In connection with the outlined approach the interpretation methods are all epistemological means of the recognition. "Legal understanding recognizes the theoretical and practical importance of linguistic, textual (hermeneutical), structuralist, logical-analytical, legal-dogmatic directions, techniques and means of studying the problems of law" $" 12$.

In view of this, let us try to distinguish the characteristic features of the ways of interpreting the rules of law, to which we consider it appropriate to include the following:

1) ways of interpreting legal rules include techniques and rules for the interpretation of legal rules;

2) the ways in which legal rules are interpreted make it possible to comprehensively understand the content of a legal rule;

3) ways of interpreting legal norms contribute to the realization of law by defining the true content of the legal norm and bringing it to the attention of the subjects of law and subjects of law;

4) ways of interpretation of legal norms ensure the comprehensiveness and complexity of the interpretation of legal rules;

5) ways of interpretation of legal norms are implemented in the activities of the subjects of interpretation of law, the content of which is the internal mental process of establishing the content of the legal norm in the mind of the subject of interpretation of the rule of law;

6) the ways of interpreting legal norms determine the official or informal nature of the interpretation of legal norms;

7) ways of interpretation of legal norms are conditioned by the content of the legal norm and the professional level of the subjects of interpretation of the rule of law;

8) the ways of interpreting legal norms ensure the effectiveness of the interpretation of legal norms in general, which consists in providing a reasonable answer regarding the content of the will of the law-maker, which is enshrined in the legal norm;

9) the application of methods of interpretation of legal norms is reflected in the content of the act of interpretation of legal norms, which has an individually determined character ${ }^{13}$.

There is no single approach to the classification of ways of interpretation in the literature.

12 Nersesyants V.S. (2006). Filosofiya prava [Philosophy of Law] ucheb. dlya vuzov. (2nd ed., rev.) (p. 91) Moscow: Norma [in Russian].

${ }^{13}$ Sposib tlumachennja pravovykh norm jak jurydychna kateghorija [Method of interpreting legal norms as a legal category] (issue 21, part 2, Vol. 1) Serija Pravo. [in Ukrainian]. 
The most common is the classification of ways of interpretation into linguistic, logical, systemic (systematic), historical ${ }^{14}$.

E. Vaskovskii proposed the concept of division of the interpretation into literal and real interpretation, which reflects the coverage of the appropriate type of interpretation of the application of techniques aimed at establishing the literal meaning of the text of the law, or its "true, internal meaning" 15 . At the same time, the author determined that the method of grammatical interpretation is used for the literal interpretation, and the logical methods of interpretation are characteristic for the real one.

A. Cherdantsev noted that interpretation is a process of logical deduction and proving the truth of our knowledge about the content of the rules of law, in the process of which all the laws and techniques in the arsenal of logic are applied. From this point of view, he pointed out, that all ways of interpretation are logical ${ }^{16}$. Thus, according to the "form" of the existence of a rule of law the following ways of interpretation are called: linguistic, systematic, historical and functional ${ }^{17}$.

Further, the author notes that in the process of interpretation the interpreter operates with the help of logical techniques the material of the most interpreted norm, without going beyond its boundaries, without resorting to other norms of law (the conclusion from the opposite, the emergence of concepts, analogy, etc.), so it is advisable totality of such to call techniques a logical way of interpretation ${ }^{18}$.

S. Alekseev as a logical way understands the meaning of the rule of law through the use of laws and rules of formal logic; analysis not of words and expressions, but of the concepts they reflect ${ }^{19}$. According to him, this method allows to reveal the content of legal norms, which sometimes does not coincide with the literal meaning due to the unsuccessful choice by the legislator of verbal forms.

${ }^{14}$ Shemshuchenko Yu.S. (Eds.) (2003). Jurydychna encyklopedija [Legal Encyclopedia] (Vols. 1-6) (Vol. 4). Kyiv: Ukrainska Encyklopediya [in Ukrainian].

15 Vas'kovskiy E.V. (1913). Rukovodstvo k tolkovaniyu i primeneniyu zakonov: dlya nachinayushchikh yuristov [Guide to the Interpretation and Application of Laws: For Beginners] (p. 32) Moscow : Br. Bashmakovykh [in Russian].

${ }^{16}$ Cherdantsev A.F. (1972). Voprosy tolkovaniya sovetskogo prava [Interpretation issues of Soviet law] (p. 79) Sverdlovsk [in Russian].

${ }^{17}$ Cherdantsev A.F. (1972). Voprosy tolkovaniya sovetskogo prava [Interpretation issues of Soviet law] (p. 81) Sverdlovsk [in Russian].

${ }^{18}$ Cherdantsev A.F. (1972). Voprosy tolkovaniya sovetskogo prava [Interpretation issues of Soviet law] (p. 81) Sverdlovsk [in Russian].

${ }^{19}$ Alekseeva S.S. (Ed.) (1987) Problemy teorii gosudarstva i prava [Problems of the theory of state and law] Moscow: Yuridichtskaya Literatura [in Russian]. 
We believe that more or less every author is right, because, as noted above, the method primarily reflects the approach of the interpreter, which is different in originality and originality.

From the analysis of the law enforcement practice of the tax authorities, it is possible to use the following methods of interpretation of tax legislation: linguistic, logical, systemic and historical, the essence of which will be analyzed in more detail below.

\section{Linguistic and logical ways of interpreting the rules of law}

The interpretation and understanding of the rules of law depends on the quality of the paper on the will of the legislator, that is, it is mediated by written text. The object of the interpretation is the text of the legal act, as is any language text. It should be noted that language plays a decisive role in the formation of society, one of the functions of the language is the stategovernment. Without language there can be no right ${ }^{20}$. The language of the law is an extremely important factor in the implementation of state will. The verbal-textual envelope of this will must not only add to the law the property of meaningful accessibility, but also harmonize the very content of the law, promote its transformation into a holistic and modern product of intellectual labor $^{21}$. In law-making it is necessary to pay particular attention to the language of the law, carefully construct each sentence, pick words and phrases, make clear and simple statement of the rule of law. This is a list of the first, simplest requirements for those involved in the creation of any law, not just the tax law.

One way to interpret the rules of law, which is especially relevant to tax law, is through linguistic interpretation. Linguistic (philological, linguistic, textual, grammatical) interpretation is the clarification of the content of a rule of law through a grammatical analysis of its verbal formulation using the laws of philology; which is based on the laws of grammar, vocabulary and assumes the analysis of words, sentences, verbal formulations of legal norms. This method is to determine the meaning of each word and expression used in the legal act, the analysis of the grammatical forms of nouns and adjectives, the ways of verbs, the type of participles and the understanding of the grammatical structure of sentences. An important disadvantage of this method is that the grammatical interpretation reveals the literal content of the rule of law, on the basis of which it is not always possible to make a reliable

\footnotetext{
${ }^{20}$ Masenko L.T. (2004). Mova i suspiljstvo: Postkolonialjnyj vymir [Language and Society: Postcolonial Dimension] Kyiv : KM Aekademija [in Ukrainian].

${ }^{21}$ Bjeljakov K.I. (2006). Informacija v pravi : teorija i praktyka [Information in law: theory and practice] (p. 77) Kyiv: KVIC [in Ukrainian].
} 
conclusion. According to A. Ushakov, philologists are only interested in the language form, only its expression, which is detached from its content, so the study of the language of regulatory acts is mostly formal ${ }^{22}$. However, in order to fully and accurately apply the rules of linguistic interpretation of texts of normative legal acts, it is advisable to observe the principle of unity of terminology, unambiguous understanding of legal terms in a particular legal system.

One cannot disagree with the clarified definition of the concept of legallinguistic interpretation given by L. Chulinda. In her view, a legal-linguistic interpretation is a set of mental operations that enable, through linguistic analysis of the content of a written document containing norms of law with the formulated intention of the ruler, to overcome possible contradictions in the understanding of norms or between norms, to clarify the meaning of individual words and text in general ${ }^{23}$.

Criticizing the positivists (especially the representatives of analytical jurisprudence), V. Nersesiants indicated that in the case of the increased interest of the latter to the linguistic and textological interpretations of the law, while explicitly ignoring its legal meaning, legal epistemology is replaced by linguistic ${ }^{24}$.

Fully endorsing the expressed objection to the linguistic approach of all legal epistemology, which would ultimately mean abandoning other ways of interpreting the law, it is also necessary to speak in defense of the linguistic way of interpreting tax legislation.

We believe, that there is an objective need for linguistic interpretation of the acts of legislation, especially tax laws. "The linguistic formulation of normative legal acts, according to the logic of things, taking into account the importance of the normative text for relations between people, ultimately for their life, should be as simple as possible" 25 . However, tax legislation is hardly easy to understand from a linguistic point of view. Many of its

${ }^{22}$ Ushakov A.A. (1983). O yazyke zakonov i zakonodatel'noy stilistike [On the language of laws and legislative style]. Struktura lingvostilistiki i ee osnovnye kategorii - The structure of linguistic stylistics and its main categories. (pp. 82-87) Perm' [in Russian].

23 Chulinda L.I. (2006). Jurydyko-linghvistychne tlumachennja tekstiv normatyvnopravovykh aktiv [Legal and linguistic interpretation of texts of normative legal acts] Kyiv: Atika [in Ukrainian].

${ }^{24}$ Nersesyants V.S. (2006). Filosofiya prava [Philosophy of Law] ucheb. dlya vuzov. (2nd ed., rev.) (p. 91) Moscow: Norma [in Russian].

${ }^{25}$ Rotanj V. (Ed.) (2008) Naukovo-praktychnyj komentar do cyviljnogho zakonodavstva Ukrajiny [Scientific and practical commentary on the civil legislation of Ukraine] (Vols. 1-4) Metodologhija tlumachennja normatyvno-pravovykh aktiv Ukrajiny [Methodology of interpretation of normative legal acts of Ukraine] (Vol. 3) (p. 480) Kyiv: Juryd.kn.; Sevastopolj: In-t juryd.doslidzhenj [in Ukrainian]. 
provisions require grammatical and syntactic analysis in order to clarify the will of the legislator.

Here is an example of the content of the paragraph of the third subparagraph 5.3.3 of clause 5.3 of Art. 5 of the Law of Ukraine "On Corporate Income Taxation", which was in force until the adoption of the Tax Code of Ukraine. It stated that "If the payer of income tax registered as a payer of value added tax simultaneously carries out transactions for the sale of goods (works, services), which are subject to value added tax and are exempt from taxation with such a tax, the value added tax paid as part of the cost of acquiring goods (works, services) related to gross expenses and fixed assets and intangible assets subject to depreciation is included in accordance with the gross cost or book value of the group assets increased by an amount not included in the tax credit the taxpayer pursuant to the Law of Ukraine "On Value Added Tax". The logical structure of the complex sentence being analyzed requires revision and suggests the addition of the conjunction "so that" before the selected words "value added tax".

In the new version of the Tax Code of Ukraine, legislators try to avoid such problems that existed in previous tax laws.

Let us turn to the case law which uses a method of linguistic interpretation.

In one of the cases reviewed by the Supreme Court of Ukraine on December 2, 2015, there was a need to interpret Art. 71, 72, 74 of the Tax Code of Ukraine. The court concluded that in such circumstances, the actions of the supervisory authority regarding the entry into the electronic database of information obtained as a result of the tax audit, including the result obtained by the act, were only the official activity of employees of the tax authority in fulfillment of their professional duties to collect evidential information regarding the presence or absence of documentary confirmation of the respective operations, unless the actions for the exercise of such control are found unlawful in the institution order. These actions alone do not create for the taxpayer any legal consequences in the form of change or termination of his rights and do not give rise to binding legal consequences for him.

It is a matter of fixed substantive law. For example, on the one hand, granting the customs declaration the status of tax, on the other - the establishment as a mandatory requisite of the tax bill of goods in accordance with UCT ZED (Ukrainian Classification of Goods for Foreign Economic Activity) (Art. 201 of the Tax Code of Ukraine).

Thus, the need for linguistic interpretation of tax law acts results from the objective textual complexity of the latter, the need to clarify the etymology of a particular term, and in some cases to correct any syntactic and stylistic errors. However, linguistic interpretation should not be confused with the concept of "literal interpretation", which does not go beyond the "letter of the 
law" and imposes a prohibition in the methodological plan on any logical refinement of the provisions of the law, which traditionally contrasts with interpretation using the methods of logical transformation of norms and associative interpretations.

The provisions of legislative acts are the result of understanding by the law-making bodies of reality, set out in the form of normative text through the main means of social communication - language, that is through words, sentences, groups of sentences. Human language obeys the logic that is inherent in human consciousness. The logic is guided by both those who seek to convey their thoughts and those who seek to perceive them. This also applies to law-enforcement bodies which, within the limits of their powers, inform their respective entities through legal acts and addressees of those requirements. The addressees understand the provisions set out in the regulations, because they have the same reasoning logic as the law-making body. With this in mind, any interpretation of regulations is a logical interpretation, but it does not prevent the identification of certain ways of interpretation and designation by special terms without the use of the word "logical". However, even after isolating the relevant types of interpretation, logical interpretation still has some meaning. This justifies the use of the term "logical interpretation of legal acts (regulations, acts of law)".

By means of logical interpretation, the provisions of legal acts reveal the legal content, which is not textually expressed in them.

A large part of the provisions required logical interpretation, which were in force before the adoption of the Tax Code of Ukraine, which in the example of par. 17.3. Art. 17 of the Law of Ukraine "On the procedure for paying off taxpayers obligations to budgets and state trust funds", according to which the payment (collection) of penalties provided for in this Article shall be equal to the payment (collection) of the tax and the appeal of their amounts. Carrying out a logical analysis of the stated norm, we will conclude that the word "appeal" is omitted in the first part of this rule, since in the current wording it turns out that the payment (penalty) of penalties equates to the payment (charge) of tax and the appeal of their amounts. However, it is obvious that the payment (penalty) of penalties cannot simultaneously be equal to the payment (charge) of the tax and to the appeal of their sums, since these are different concepts.

Thus, in previous laws, the appeal of the tax liability determined by the tax authority is regulated by par. 5.2.2. of this Law, and payment and recovery par. 15.1.1., which sets the statute of limitations.

On the basis of the above, it is necessary to state the reasons for presenting the analyzed provision in the following wording: "payment (penalty) of 
penalties and appeal of their sums stipulated by this Article shall be equal to payment (charge) of tax and appeal of their amounts".

Today, in the current version of the Tax Code, the same rules have remained, but in a different interpretation: appeals against decisions of regulatory bodies are regulated by Art. 56 of the PC (Tax Code) of Ukraine, and payment of the monetary obligation is determined in par. 14.1.39 of the PC (Tax Code) of Ukraine; limitation period provided by Art.102 PC (Tax Code) of Ukraine.

The example that will be set forth here, is particularly illustrated by the fact that, without taking into account legal prescriptions that are indirectly derived from acts of law and which are found when interpreted by a conclusion on the basis of incomplete logical identity (a fortiori), enforcement loses its legal character and acquires and even vulgar positivism.

This is a different interpretation of subpar. (a) of par. 7.7.2 of part 7.7 of Art. 7 before the current Law "On Value Added Tax": "Budget compensation is subject to ... part of the negative value (liability for value added tax Auto.), which is equal to the amount of tax actually paid by the recipient of goods (services) in the previous tax period to suppliers of such goods (services). "In one case, the court found that the amount of the budgetary compensation could not take into account the amount of value added tax paid in the tax period that preceded the aforementioned prior tax period. This was strictly in line with the law, which the court had read harshly with the signs of positivism referred to above. The plaintiff was outraged by the judgment and characterized the legislative provision on the basis of which he was denied the claim and which was cited above as inanimate and technocratic.

Another court interpreted the same legislative provision as follows: "Within the meaning of subpar. (a) of par. 7.7.2 of Art. 7 of the Law on "Value Added Tax", when determining the amount of budgetary compensation, account should be taken of the value added tax paid by the plaintiff in the composition of the price of goods not only in the previous tax period, but also in all tax periods that preceded the previous tax period; provided that these amounts have not previously been included in the tax credit or taken into account in determining the amount of budgetary compensation".

If we read carefully this fragment of the court order and compare it with the previous one, one can see how the letter of the law comes to life in the given court fragment, thanks to the intuition of experienced judges, as it deprives itself of the signs of technocratism and acquires the signs of rationalism, sociality, civilization.

But it also draws attention to the fact that the content of the last ruling of the court was adopted without reliance on science, on the basis of intuition 
with reference to the meaning of the law. This court order would have become scientific if the court had so motivated its decision: "Subparagraph" a "of par. 7.7.2 of part 7.7 of Art. 7 of the Law "On Value Added Tax" prescribes when determining the amount of budgetary compensation to take into account the value added tax paid by the payer of such tax in the price of goods in the previous tax period. From this provision indirectly follows and a fortiori conclusion reveals a legal prescription according to which value added tax paid by the payer of value added tax in the periods preceding the tax period, which in subpar. 7.7.2 part 7.7 of Art. 7 of the Law "On value added tax" is marked as preliminary, the more it should be taken into account in determining the amount of budgetary compensation claimed by the taxpayer for the reporting tax period, provided that the payer of value added tax or not previously exercised the right to a tax credit or did not take into account the value added tax paid in the periods preceding the previous tax period when determining the amount of budgetary compensation.

It is interesting how the legislator responded to the lack of certainty that the provisions of subpar. "a" of par. 7.7.2 of part 7.7 of Art. 7 before the current Law on Value Added Tax due to lack of methodology for interpreting acts of legislation. By the Law "On the State Budget of Ukraine for 2008 and Amendments to Certain Legislative Acts of Ukraine" in this paragraph the words "in the previous tax period" were replaced by the words "in the previous tax periods". The same wording is used in par "a" of part 200.4 of Art. 200 PC. (Tax Code).

Thus, the results of the logical interpretation of tax laws can formulate a more successful and logically correct formulation of the interpreted provision.

The content of the logical way of interpretation is specified in its techniques, which are the logical transformation of the provisions of the law. The conformity of such a transformation to the requirements of logical (correct) thinking, that is, to the laws of logic, is a criterion for delimiting the interpretation made in this way from interpretation contrary to law.

\section{Systematic, historical and teleological ways of interpreting the rules of law}

It should be noted that the rules of law are interconnected with each other, that is, in a particular system. This is the reason for determining the content of individual rules by comparing them and tracing relationships with other rules of law. According to N. Onishchenko, the systematic way of interpretation is to identify the interconnection and interaction of legislative acts, the harmonization of each new legislative act with the constitutional norms, acts 
of their own and other branches of law, as well as those that provide legal liability for violations of existing legislation ${ }^{26}$.

The interpretation of a rule of tax law must be based on the consideration of a particular rule as part of the general system of law. Failure to do so may result in a gross violation of the law, rights and interests of taxable persons. Courts resort to a systematic interpretation of the law to find out the logical relationship between legal categories, that is, for example, the generic belonging of one concept to another.

For example, in one case the Supreme Court of Ukraine stated: "as follows from the systematic analysis of par. 1.1. and 1.2 Art. 1 of the Law of Ukraine On the Procedure for Repayment of Taxpayers' Obligations to the Budgets and State Trust Funds of 21.12.2000 No. 2181-III, which at that time settled controversial relationships, under the taxpayer's tax liability in the context of subpar. 15.1.3. par. 15.1 of Art. 15 should be understood as the amount of tax (principal payment), as well as penalties and penalties."

In a ruling of the Supreme Court of Ukraine of November 17, 2015, a panel of judges found that judges of previous instances had violated par/ 74.1 of Art. 74 of the PC (Tax Code) of Ukraine, stating that tax information collected under this Code could be stored and processed in the control databases bodies or directly by the officials (officials) of the controlling bodies.

On the basis of the act, the Inspectorate adjusted the Company's tax reporting indicators in all information bases of the State Tax Service bodies and made changes to the respective system, thereby reducing the amount of tax credit and tax liabilities by counterparties for April 2014.

The conclusions set out in the act are a reflection of the actions of tax inspectors, do not give rise to legal consequences for the taxpayer, and, accordingly, such an act does not violate the latter's rights.

The inclusion of the power of the subject in the database of information about such verification does not create any obstacles for the activity of the taxpayer.

Based on the systematic interpretation of Art. 71, 72, 74 of the PC (Tax Code), the panel of judges concluded that the information received from the tax control was used for the information and analytical support of the activity of the controlling body and could not be excluded from the databases if such control was carried out. not found unlawful in due course. Therefore, such submissions on the basis of the act are unjustified.

${ }^{26}$ Onishhenko N.M. (2002). Pravova systema i derzhava v Ukrajini [Legal system and state in Ukraine] Kyiv: Instytut derzhavy i prava im. V.M. Korecjkogho NAN Ukrajiny [in Ukrainian]. 
A similar legal position on the application of these substantive law rules has already been expressed by a panel of judges of the Judicial Chamber in administrative cases of the Supreme Court of Ukraine in its rulings of December 9, 2014 (Case No. 21-511a14).

An example of a systematic interpretation may also be the decision of October 29, 2014 in Case K / 9991/25760/12, in which the Supreme Administrative Court of Ukraine, by establishing the procedure for repayment of taxpayer's obligations, performs a comprehensive analysis of tax legislation. In doing so, the court provides clarification on the sequence of stages of tax debt recovery. Yes, the tax authority has the right to use the property of the payer to repay his tax debt in case of insufficient or lack of funds in the accounts of the enterprise or lack of information about the existence of such accounts at all. According to the content of Art. 95 of the Tax Code of Ukraine, it does not follow that the tax authority has the right to go to court for permission to pay off tax debt at the expense of the payer's property, bypassing the stage of collection of funds from the taxpayer to pay off his tax debt.

In its ruling of April 12, 2016, in the case No. 21-240a16, the Supreme Court of Ukraine, analyzing the legal norms for imposing a levy on the taxpayer, using a systematic way of interpretation, produces the grounds on which the taxpayer may be held liable on the basis of par. 123.2 of Art. 123 PC (Tax Code) in the form of tax collection of taxes, fees (compulsory payments), which are subject to accrual without applying a tax benefit. Yes, the court notes that such liability can only be applied in the presence of statutory purposes and / or conditions or purposes of using sums of funds not paid to the budget, and provided that proving the use of such sums is not for the purpose and / or contrary to the conditions or purposes defined by law. Article 18 of the Law of Ukraine of March 19, 1996 No. 93/96-BP "On the regime of foreign investment", according to which the Company was exempted from the payment of duties on import of a bus, as well as the said Law as a whole, did not specify the purpose and / or conditions or purposes of using the amounts of funds that were not paid to the budget as a result of the application of the privilege established by it, therefore the application to the Society of the established par. 123.2 of Art. 123 PC (Tax Code) liability is unfounded.

Therefore, as the law of practice shows, systematic and logical ways of interpreting tax law norms are perhaps the most common, which is understandable given the complex nature of tax law. However, in order to find out the true will of the legislature of the court, a systematic way of interpretation is not enough.

The need for a historical interpretation of the rule of law arises quite often. This method is to compare the applicable rule of law with those previously applied. An interpreter examines normative material in a historical, 
retrospective or perspective perspective that facilitates an understanding of the purpose of adopting or amending this legal rule. Historical interpretation makes it possible to understand more fully and fully the meaning that the legislator sought to bring into force. However, not all scholars identify the historical way of interpreting the rules of law as independent. According to A. Bonner, historical interpretation is a kind of systemic. It takes into account the historical aspect of the legal system ${ }^{27}$.

Very successful is the statement about the historical way of interpreting the rules of law of the French theorist J.-L. Bergell, the historical method is based on the idea that law is a process, a dynamic act of society, and laws act only as a temporal reflection, which must evolve with the changing social environment. Thus, laws can be removed from the original will of the legislator and make new sense in order to adapt to current requirements that are put forward by reality ${ }^{28}$.

Thus, in the blighty system of legislation, the historical method of interpretation is subject to all rules of law adopted before 1991, that is during the Soviet Union. The inertia of the domestic lawmaker in the replacement of obsolete norms of law leads to the fact that many important spheres of public life have for a long time been regulated (and in some cases continue to be regulated today) by rules adopted in the context of Soviet realities. Indicative examples are the Labor Code of Ukraine (1972), the Residential Code of Ukraine (1983), and the Code of Administrative Offenses (1984), which remain in force. Although a considerable number of fragmentary changes have been introduced to these codes since 1991, this does not solve the problem of their interpretation, since the concept of legal regulation of public relations is outdated ${ }^{29}$.

Let us turn to the enforcement example. At present, the Tax Code of Ukraine does not provide legal regulation of state liability for late payment of the amount of budget compensation. Therefore, the question arises whether this is a gap in legal regulation, or the absence of a relevant provision in the law is the will of the legislator.

As the task of interpretation is "to find out the opinion and will of the legislator" ${ }^{\prime 30}$, then in the absence of the will of the legislator to directly regulate the

27 Bonner A.T. (1980) Primenenie normativnikh aktov v grazhdanskom protsesse [Application of normative acts in civil procedure] (p. 19) Moscow: Yuridichtskaya Literatura [in Russian].

${ }^{28}$ Berzhel' Zh.-L. (2000). Obshchaya teoriya prava [General Theory of Law]. Danilenko V.I. (Ed). (Churshukova G.V. Trans.) (p. 432) Moscow: NOTA BENE [in Russian].

${ }_{29}$ Kryvycjkyj Yu.V. (2012). Istorychnyj sposib tlumachennja norm prava: zaghaljnoteoretychnyj aspekt [The historical way of interpreting the rules of law: a general theoretical aspect] (pp. 32-36) Kyiv: Chasopys Kyjivsjkogho universytetu prav [in Ukrainian].

30 Vas'kovskiy E.V. (1913). Rukovodstvo k tolkovaniyu i primeneniyu zakonov: dlya nachinayushchikh yuristov [Guide to the Interpretation and Application of Laws: For Beginners] (p. 34) Moscow : Br. Bashmakovykh [in Russian]. 
liability of the state for delayed fulfillment of the obligation to pay budgetary compensation, it is impossible to speak about the existence of a gap.

However, the absence of a reference in the Tax Code of Ukraine on the responsibility of the state for late payment of budget compensation does not indicate the existence of a gap.

The role of historical interpretation of tax law may also be to establish the existence or absence of a gap in the legal regulation of tax relations. If, as a result of the historical interpretation of the tax law act, it turns out that the legislator had previously settled a certain tax issue, and in the current legislation there was no such or any other regulation, then it is impossible to conclude unequivocally the existence of a gap in law, because the law itself, as stated above, the phenomenon is dynamic. Since the adoption of the previous legal norms, other regulations could be adopted to regulate this issue. Therefore, other ways of interpreting, in particular, systemic ones, should be used to conclude that there is or should not be a specified gap.

The following will also be illustrative of the possibility of an effective use of the historical way of interpreting tax law. As Art. 26 of the Law of Ukraine "On Freedom of Conscience and Religious Organizations" of April 23, 1991 No. 987-XII specifies that the legislation of labor, generally applicable, applies to citizens who work in religious organizations and enterprises, charitable institutions established by them under the terms of an employment contract. state social insurance, taxation. At present, the provisions of the Tax Code do not include the concept of "tax legislation", such term was included in the legislative acts that were in force prior to the adoption of the Tax Code. Currently, the term "taxation legislation" is replaced by "tax law." Therefore, based on the "letter of the law", its provisions would be inapplicable at this time, but the subject of interpretation, knowing that in historical retrospect, the term "taxation legislation" has been transformed into "tax law", applies the current provisions of tax law.

It should be noted that, in addition to the above methods of interpretation, scientists also identify a teleological way of interpretation. The teleological method of interpretation is closely related to the methods of interpretation described above. P. Rabinovich points to the relationship of teleological and historical mode of interpretation. So, the historical way of interpretation is to establish what came before the publication and at the time of the law, and the teleological way of interpretation reveals what will (should) be after the implementation of the law in life ${ }^{31}$.

${ }^{31}$ Rabinovich P.M. (1966). Sotsialisticheskaya zakonnost' i tselesoobraznost' v sovetskom prave [Socialist legality and expediency in Soviet law] Extended abstract of candidate's thesis. Moscov [in Russian]. 
T. Nasirov, justifying the independence of the teleological way of interpretation, rightly points out that all ways of interpretation contribute to clarifying the purpose of the rule of law, but at the same time none of them is interpreted in accordance with its purpose. In this regard, the author sees the specifics of the teleological method of interpretation in that it investigates an objective result, aimed at the implementation of a norm that goes beyond the internal logical content of the rule of law and does not coincide with the analysis of the relationship of the norm with other prescriptions. In this respect, the teleological method of interpretation is not covered by other means, since it is the only one that is directly aimed at clarifying the meaning of a rule of law, depending on the results that should be achieved in its implementation ${ }^{32}$.

Considering that the goal is the basic structural element of the rule of law, and the form and content act as means to achieve it, it is not surprising that the structure of techniques of the teleological method of interpretation is a place for the elements of logical, linguistic and systematic ways of interpretation. The rule of law has a strong willed character, that is, a power commandment, which establishes a certain obligatory variant of the behavior of the subjects in one or other circumstances.

B. Malyshev exploring the teleological method of interpretation points to specific techniques of this method of interpretation, namely: the possibility of determining the purpose of the rule of law by correlating it with the relevant norms-goals. As the author rightly points out, at first glance, this technique duplicates the reception of a systematic interpretation of the relationship of the interpreted rule with the principle of law, but in the teleological way, the relationship between the principle and the norm is considered in the context of the meta-means model, and not in the context of a systemic interpretation model ("whole - part", "abstract - concrete") ${ }^{33}$.

The opinion of Judge of the Permanent Chamber of International Justice in the League of Nations M. Antsilotti remains relevant, according to which it is impossible to conclude on the true purpose of an article of any convention until its goals and objectives have been determined. Therefore, these questions must be answered before interpreting ${ }^{34}$.

32 Nasyrova T.Ya. (1988). Teleologicheskoe (tselevoe) tolkovanie sovetskogo zakona. Teoriya i praktika [Teleological (target) interpretation of Soviet law. Theory and practice] (pp. 69-71) Kazan' : Izd-vo Kazanskogo universiteta [in Russian].

33 Malyshev V.P. (2011). Teleologhichnyj sposib tlumachennja norm prava: zaghaljnoteoretychni aspekty [The teleological way of interpreting the rules of law: general theoretical aspects] Kyiv: Advokat (10 (133) ed.) (p. 7-14) [in Ukrainian]

${ }^{34}$ European Court of Human rights, Engel and Others v. the Netherlands judgment of 8 June 1976. European Court of Human Rights Portal. Retrieved from www.echr.coe.int. 


\section{CONCLUSION}

The Constitution of Ukraine incorporates the best global experience of constitutional regulation of public relations. It directs ongoing law-making activities. Therefore, Ukraine has a system of legislation that meets the needs of intensive progressive development of political, economic, social spheres, the needs of affirmation of human honor and dignity, its moral, intellectual and physical development. The task is only to ensure the implementation of the Constitution, laws and other legislative acts. The leading role in this belongs to the law enforcement agencies.

But the law enforcement agencies can fulfill their part of the task of introducing into the public relations of the Constitution, laws of Ukraine and other acts of legislation only on condition that they will have perfect tools for rational elaboration of the provisions of the Constitution, laws, and other legal acts. One of the rational tools for elaborating normative legal acts is the methods of interpretation, which are determined by the set of techniques and means used by the law enforcement agency in determining the content of the legal norm.

The main ways of interpreting normative legal acts are: philological (linguistic), logical, systemic, historical and teleological.

The correct application of the provisions of acts of taxation legislation can be ensured by the methodology of their interpretation, if it is possessed by tax authorities, judges and other specialists working with the relevant acts.

\section{SUMMARY}

The article is devoted to the actual problem of ways of interpreting acts of the legislation of Ukraine on taxation. The need for a transition from an intuitive to a rational approach to drafting tax legislation was emphasized. The scientific approaches to the definition of "ways of interpretation" are covered. The role of ways of interpreting tax legislation acts in determining whether or not there is a gap in the legal regulation of tax relations is analyzed. Approaches to the classification of ways of interpretation are investigated and the methods and problems of interpretation of acts of taxation legislation are characterized. The importance and necessity of applying such methods of interpretation as linguistic, logical, systemic, historical and teleological are analyzed in practice. An analysis of the norms of the current tax legislation as well as the legislation that has been in force is given, taking into account the methods of interpretation specified by the author. The purpose and results of the interpretative activity of tax legislation acts are determined. 


\section{REFERENCES}

1. Alekseev S.S. (1999). Sotsial'naya tsennost' prava $v$ sovetskom obshchestve [The social value of law in Soviet society]. Moscow: Yuridichtskaya Literatura [in Russian].

2. Berzhel' Zh.-L. (2000). Obshchaya teoriya prava [General Theory of Law]. Danilenko V.I. (Ed). (Churshukova G.V. Trans.) Moscow: NOTA BENE [in Russian].

3. Bjeljakov K.I. (2006). Informacija $v$ pravi : teorija $i$ praktyka [Information in law: theory and practice] Kyiv: KVIC [in Ukrainian].

4. Bonner A.T. (1980) Primenenie normativnikh aktov v grazhdanskom protsesse [Application of normative acts in civil procedure] Moscow: Yuridichtskaya Literatura [in Russian].

5. Vas'kovskiy E.V. (1913). Rukovodstvo $k$ tolkovaniyu i primeneniyu zakonov: dlya nachinayushchikh yuristov [Guide to the Interpretation and Application of Laws: For Beginners] Moscow : Br. Bashmakovykh [in Russian].

6. Voplenko N.N. (1993). Tolkovanie prava. Obshchaya teoriya prava [The interpretation of law. General Theory of Law] kurs lektsiy. Nizhniy Novgorod [in Russian].

7. Keljman M.S., Murashyn O.Gh. (2006). Zaghaljna teorija derzhavy $i$ prava [General theory of state and law] Kyiv: Kondor [in Ukrainian].

8. Kryvycjkyj Yu.V. (2012). Istorychnyj sposib tlumachennja norm prava: zaghaljnoteoretychnyj aspekt [The historical way of interpreting the rules of law: a general theoretical aspect] Kyiv: Chasopys Kyjivsjkogho universytetu prav [in Ukrainian].

9. Malyshev V.P. (2011). Teleologhichnyj sposib tlumachennja norm prava: zaghaljnoteoretychni aspekty [The teleological way of interpreting the rules of law: general theoretical aspects] Kyiv: Advokat (10 (133) ed.) [in Ukrainian].

10. Masenko L.T. (2004). Mova i suspiljstvo: Postkolonialjnyj vymir [Language and Society: Postcolonial Dimension] Kyiv : KM Aekademija [in Ukrainian].

11. Nasyrova T.Ya. (1988). Teleologicheskoe (tselevoe) tolkovanie sovetskogo zakona. Teoriya i praktika [Teleological (target) interpretation of Soviet law. Theory and practice] Kazan' : Izd-vo Kazanskogo universiteta [in Russian].

12. Rotanj V. (Ed.) (2008) Naukovo-praktychnyj komentar do cyviljnogho zakonodavstva Ukrajiny [Scientific and practical commentary on the civil legislation of Ukraine] (Vols. 1-4) Metodologhija tlumachennja normatyvnopravovykh aktiv Ukrajiny [Methodology of interpretation of normative legal acts of Ukraine] (Vol. 3) Kyiv: Juryd.kn.; Sevastopolj: In-t juryd.doslidzhenj [in Ukrainian]. 
13. Nersesyants V.S. (2006). Filosofiya prava [Philosophy of Law] ucheb. dlya vuzov. (2nd ed., rev.) - Moscow: Norma [in Russian].

14. Onishhenko N.M. (2002). Pravova systema $i$ derzhava v Ukrajini [Legal system and state in Ukraine] Kyiv: Instytut derzhavy i prava im. V.M. Korecjkogho NAN Ukrajiny [in Ukrainian].

15. Alekseeva S.S. (Ed.) (1987) Problemy teorii gosudarstva i prava [Problems of the theory of state and law] Moscow: Yuridichtskaya Literatura [in Russian].

16. Rabinovich P.M. (1966). Sotsialisticheskaya zakonnost' $i$ tselesoobraznost' $v$ sovetskom prave [Socialist legality and expediency in Soviet law] Extended abstract of candidate's thesis. Moscov [in Russian].

17. Sposib tlumachennja pravovykh norm jak jurydychna kateghorija [Method of interpreting legal norms as a legal category](issue 21, part 2, Vol. 1) Serija Pravo. [in Ukrainian].

18. Todyka Yu.M. (2001). Tlumachennja konstytuciji i zakoniv Ukrajiny: teorija i praktyka: monoghraf [Interpretation of the constitution and laws of Ukraine: theory and practice: monograph] Kharkiv: Fakt [in Ukrainian].

19. Ushakov A.A. (1983). O yazyke zakonov i zakonodatel'noy stilistike [On the language of laws and legislative style]. Struktura lingvostilistiki i ee osnovnye kategorii - The structure of linguistic stylistics and its main categories. Perm' [in Russian].

20. Cherdantsev A.F. (1972). Voprosy tolkovaniya sovetskogo prava [Interpretation issues of Soviet law] Sverdlovsk [in Russian].

21. Chulinda L.I. (2006). Jurydyko-linghvistychne tlumachennja tekstiv normatyvno-pravovykh aktiv [Legal and linguistic interpretation of texts of normative legal acts] Kyiv: Atika [in Ukrainian].

22. Shemshuchenko Ju.S. (Eds.) (2003). Jurydychna encyklopedija [Legal Encyclopedia] (Vols. 1-6) (Vol. 4). Kyiv: Ukrainska Encyklopediya [in Ukrainian].

23. European Court of Human rights, Engel and Others v. the Netherlands judgment of 8 June 1976. European Court of Human Rights Portal. Retrieved from www.echr.coe.int.

\section{Information about the author:}

Igor Samsin,

Honored Lawyer of Ukraine, Doctor of Laws, Docent, Professor at the Department of Constitutional,

Administrative and Financial Law, Khmelnytsky University of Management and Law 8, Heroyiv maydanu str., Khmelnitsky, 29000, Ukraine

ORCID ID: orcid.org/0000-0003-4118-8452 